\title{
Okul Öncesi Eğitimde Aile Katılımı: Anne ve Baba Görüşleri
}

\section{Family Involvement in Preschool Education: Parents' Views}

\author{
Maide Orçan-Kaçan ${ }^{1}$ Zeynep Dönmez ${ }^{2}$ İlayda Kimzan ${ }^{3}$
}

\begin{tabular}{|c|c|}
\hline $\begin{array}{l}\text { Anahtar Kelimeler } \\
\text { Aile katılımı, } \\
\text { Okul öncesi eğitim }\end{array}$ & 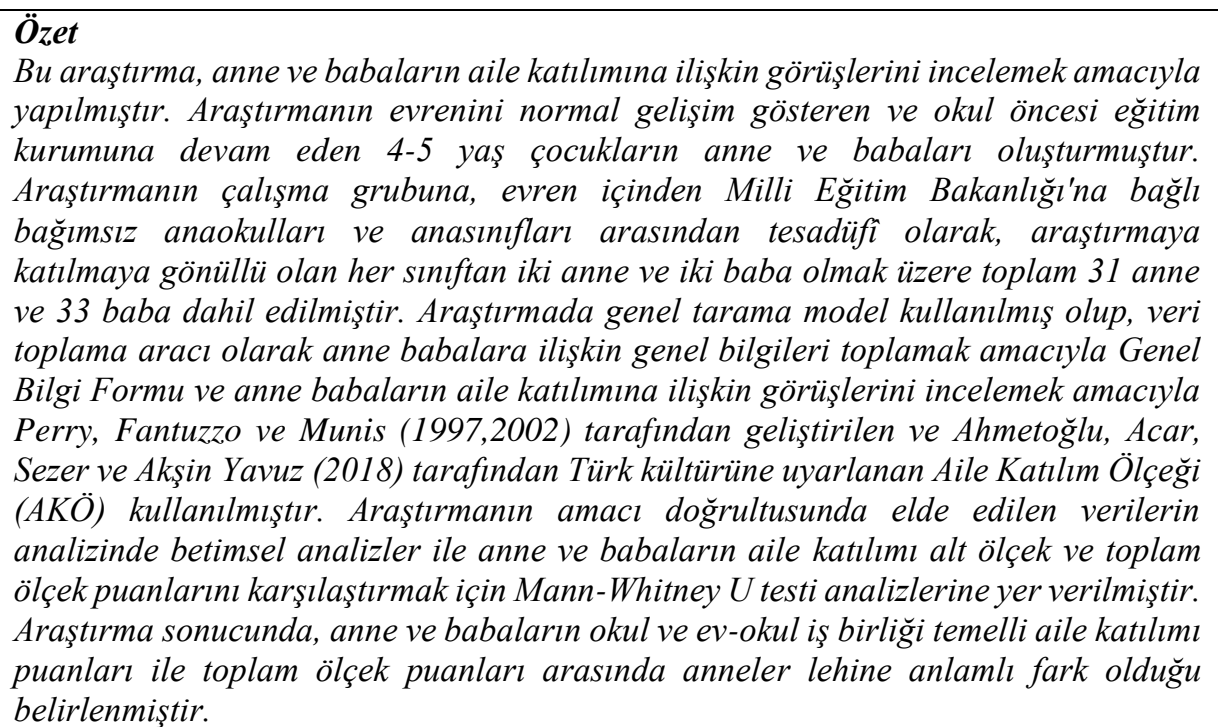 \\
\hline $\begin{array}{l}\frac{\text { Key Word }}{\text { Parent involvement, }} \\
\text { Preschool education. }\end{array}$ & $\begin{array}{l}\text { Abstract } \\
\text { This study aims to examine the views of parents about family participation. The } \\
\text { population of the study is composed of parents of } 4-5 \text { years old children who develop } \\
\text { normally and attend preschool education institution. A total of } 31 \text { mother sand } 33 \\
\text { fathers, including two mothers and two fathers from each class who voluntarily } \\
\text { participated in the study, were included in the study group of the study, among the } \\
\text { independent preschools and kindergartens affiliated to the Ministry of Education. A } \\
\text { general survey model was used in the research. As data collection tools General } \\
\text { Information Form and Family Participation Scale is used. Family Participation Scale } \\
\text { was developed by Perry, Fantuzzoand Munis (1997, 2002) and adapted toTurkish } \\
\text { culture by Ahmetoglu, Acar, Sezer and Aksin Yavuz (2018). In the analysis of the data, } \\
\text { descriptive analysis and Mann-Whitney U test analyzes were used to compare the } \\
\text { parents participation subscale and total scale scores. As a result of this search, it was } \\
\text { determined that there was a significant difference between the parents' school and } \\
\text { home-school cooperation based family participation scores and total scale scores in } \\
\text { favor of mothers. }\end{array}$ \\
\hline
\end{tabular}

\begin{abstract}
Atıf için: $\quad$ Orçan-Kaçan, M., Dönmez, Z., \& Kimzan, İ. (2020). Okul öncesi eğitimde aile katılımı: anne For Citation ve baba görüşleri. Muğla Sıtkı Koçman Üniversitesi Eğitim Fakültesi [MSKU Journal of Education], 7(2), 170-179. DOI: 10.21666/muefd.694389
\end{abstract}

Received: 25.02.2020 $\quad$ Accepted: 23.09.2020 $\quad$ Published: 01.11.2020

Günümüzde aile, eğitimde katılımcı olarak değil ana bileşen olarak görülmektedir. Eğitimin sadece okullarda verilmesi ve öğretmenin sorumluluğu altında olması ile ilgili algı tamamen değişmiştir. Aileyi eğitimin dışında tutmak artık mümkün değildir. Bu nedenle eğitimin çocuğun yaşamının tümüne yayılması kaçınılmaz olmuştur. Özellikle okul öncesi dönemde çocukların okula alışması, okulda yapılan uygulamaların evde devam etmesinin sağlanması, okul ve ev arasındaki tutarlılığın artması ve

\footnotetext{
${ }^{1}$ MSKÜ, EF, Temel Eğitim Bölümü, maideorcan@gmail.com, ORCID:0000-0003-1415-437X

${ }^{2}$ Gazi Üniversitesi, YL Öğrencisi, , zeynepdonmez99@gmail.com, ORCID:0000-0001-9426-2279

${ }^{3}$ MSKÜ, EF, Temel Eğitim Bölümü ilayda.kimzan@ gmail.com, ORCID:0000-0002-0743-3162
} 
çocuğun gelişimine çok yönlü katkı sağlaması açısından okul ve ailenin iş birliği önemlidir (Tezel Şahin ve Özyürek, 2016).

Erken çocukluk döneminde çocuklara verilen eğitim, çocuğun yaşamının geri kalanını etkileyecek öneme sahiptir. Bu dönemde çocuğun ilk eğiticileri anne baba daha sonra da öğretmen olmaktadır. Çocuklar yaşadıkları aile ortamında ilk öğrenmeleri gerçekleştirmekte olup daha sonra okul ortamında öğrendiklerini pekiştirmektedir. Aile katılımı yardımıyla anne babalar öğretmen tarafından bilgilendirilerek desteklenmekte ve ailelerin katkısıyla eğitim daha da zenginleşmektedir. Aynı şekilde ögretmen ailelerden gelen bilgiler ve geri dönütler 1şı̆̆ğnda öğrenme ortamını zenginleştirmektedir (Cömert ve Güleç, 2004). Aile katılımı ile hedeflenen sadece çocuğun eğitiminin desteklenmesi değildir. Aynı zamanda aileler de aile katılımı ile bilgi ve beceri kazanabilmektedir. Bu yollaanne babalar çocukları hakkında bilgi edinmekte, böylelikle çocukları ile daha sağlıklı iletişim kurabilmekte ve bunun sonucunda da kendilerine güvenlerinin yükselmesi hedeflenmektedir (Özel,Çağdaş ve Konca, 2016).Aile katılımı, çocukların okul başarısı ile birlikte ailelerin uygun becerileri öğrenmesi ve uygun ilişkiler geliştirmesini de kapsamaktadır (Keçeli Kaysıl1, 2008). Bu nedenle aile katılımı yalnız çocukların gelişiminin değil aynı zamanda anne babaların da becerilerinin geliştiği bir süreçtir (Çamlıbel Çakmak, 2010). Bu bağlamda, Bronfenbrenner tarafından geliştirilen çocuğun gelişimi ve öğrenmesi için hem aileye hem de okula odaklanan ekolojik kuram önem görmektedir. Ekolojik kuram temelde dört sistemden (mikrosistem, mezosistem, eksosistem ve makrosistem) oluşmakta ve bu sistemlerin birbiri ile etkileşimi üzerinde durmaktadır. Kuramda sistemlerin etkileşiminin davranışları şekillendirdiği görüşü benimsenmektedir. Mezosistemde yer alan aile ve okulun, çocuğun yaşamında önemli etkileri olduğu vurgulanmaktadır. Ekolojik model, ailenin eğitime dahil olmasında katkıda bulunmaktadır. Öğretmenler, yöneticiler veanne babalar tarafından bu yaklaşımın benimsenmesi ile aile katılımı artacak ve çocuğun başarısında aile katılımının önemi fark edilecektir (Bronfenbrenner, 1981; Christenson, 2004; Keçeli Kaysıl1, 2008).

Bu konuda dikkat çeken bir diğer kuram Vygotsky’nin öncülüğünü yaptığı sosyokültürel kuramdır. Kuram sosyal etkileşimin gelişim ve öğrenmede önemli bir rol üstlendiğini savunmaktadır. Sosyal çevre ve aktarılan kültür çocukların düşüncelerinin, kazanımlarının, değerlerinin kaynağını oluşturmaktadır. Sosyokültürel kuram, öğrenme ve gelişimin zihin ve çevrenin etkileşimi ile meydana geldiğini kabul etmektedir (Ergün ve Özsüzer, 2006; Günay Bilaloğlu ve Aktaş Arnas, 2019; Koch, 2018). Bireyin içine doğduğu aile ortamı en yakın çevresini oluşturmaktadır. Vygotsky'nin sosyokültürel kuramına göre çocukların en yakın çevresi olan aile, çocuğun zihinsel gelişimine etki etmektedir. Ailenin çocuğun eğitimine katılımı ise zihinsel gelişimine katkıda bulunmaktadır.

Aile katılımı, çocuğun ev ve okul olarak ikiye bölünen hayatının uyumlu bir bütünlük sağlamasına olanak sağlamaktadır (Hendrick, 1991'den aktaran, Öncül, 2011). Aile katılımı Fantuzzo, Tighe ve Childs (2000) tarafından üç boyutta ele alınmıştır. Ev temelli aile katılımı; ev ortamını çocuklara uygun hale getirmek, öğretmenin önerdiği etkinlikleri evde uygulamanın yanı sıra ebeveynlerin ev ödevlerine yardım etmesi, gününün nasıl geçtiğini sorması, kitap okuması, oyun oynamasını da içermektedir. Okul temelli aile katılımı; ailelerin sınıf içindeki etkinliklere katılması, veli toplantılarını takip etmesini içerirken okul-aile işbirliği temelli katılım;anne babalar ve öğretmenlerin iletişim halinde olmalarını içermektedir (Özel,Çağdaş ve Konca, 2016; Erkan, Uludağ ve Dereli, 2016; Günay Bilaloğlu ve Aktaş Arnas, 2019; Kurtulmuş, 2016).

Yapılan pek çok araştırmada aile ve okulu ortak paydada buluşturan modellerin hem çocukların başarısını hem de ailelerin bilgi ve becerilerini arttığı ortaya çıkmıştır (Tezel Şahin ve Özyürek, 2016). Yaşar Ekici (2017) yaptığı araştırma ile aile katılımına katılan anne babaların çocuklarının beceri düzeyi arttıkça sosyal davranış problemlerinin azaldığını ortaya koymuştur. Ayrıca aile katılımına dahil olan ailelerin çocuklarında benmerkezci problem davranışlarında azalma ve aile katılımına dahil olmayan ailelerin çocuklarında benmerkezci problem davranışlarında devamlılık söz konusu olduğu belirlenmiştir. Aile katılımı, çocuğa gelişimsel ve akademik olarak sağladığı yararların dışında anne babaların da yetenek ve becerilerini ortaya çıkarmaktadır. Aileleri bilgilendirmek, aile, çocuk ve öğretmen arasında bir bağ oluşturabilmek aile katılımının temel dayanaklarını oluşturmaktadır.

Aile katılımı, hem annenin hem de babanın ve hatta son yıllarda tüm aile üyelerinin eğitime katılması olarak tanımlanmaktadır. Her ne kadar aile katılımı anne katılımı olarak görülse de, babaların çocuğun eğitimine katılmasının olumlu sonuçlar doğurduğu bilinmektedir (Tezel Şahin ve Özyürek, 2016). Babalar çocukları ile oynamaktan zevk almakta ancak eğitim ile ilgilenmenin annelerin görevi olduğunu düşünmektedirler (Tezel Şahin ve Özbey, 2009). Son yıllarda annelerin çalışma hayatında daha fazla 
yer alması babaların çocuk gelişimindeki rolünü arttırmıştır (Gürşimşek, Kefi ve Girgin, 2007). Babalar, evin geçimini sağlama, çocuk ile ilgilenmenin annenin görevi olması vb. düşünceler ile aile katılım çalışmalarına ilgisizlik göstermektedir. Farklı olarak, babaların eğitime dahil olmaktan korktukları da düşünülmektedir. Çocuklara doğduğu andan itibaren bakım veren kişi genellikle anneler olması nedeniyle babaların çocuk eğitimine ve bakımına nasıl katılacaklarını bilmedikleri fikri (Green, 2001) araştırmacılar tarafindan ortaya atılmıştır. Fakat U.S. Department of Education (1999) tarafindan yapılan araştırmada eğitime katılan babaların çocuklarının okulda daha iyi olduğu ve daha az problemli davranış gösterdikleri sonucuna ulaşılmıştır (Akt. Tezel Şahin ve Özyürek, 2016). Babalar çocukların gelişiminde önemli bir rol üstlenmekte ve çocukların eğitimine katıldıklarında fayda sağlamaktadırlar. Aynı şekilde, sıcak baba-çocuk ilişkisi ile babaların çocukların eğitimine katılması, çocukların özgüvenini arttırmakta ve yaşıtları ile daha sağlıklı iletişim kurabilmesine yardımcı olmaktadır (Green, 2001).

Çocuğun gelişiminde ve eğitiminde hem okul hem de aile ortamı oldukça önemli bir yere sahiptir (Dodge, Colker ve Heroman, 2002; Tezel Şahin ve Özyürek, 2016). Değişen yaşam koşulları ile çocuğun çevresinden elde edeceği bilgi kaynaklarına ulaşımı güçleşmekte bu nedenle aile ve okul arasında işbirliği önem kazanmaktadır. Apartman yaşantısı, gelişen teknoloji, çalışan anne babalar çocuğun dış dünyadan elde edebileceği deneyimleri kısıtlamaktadır. Bu nedenle çocukların eğitim ve gelişimlerini üst basamaklara çıkartmak için okulda uygulanan eğitimin evde devam ettirilmesi gerekmektedir. Eğitimin hem evde hem de okulda devamlılığı açısından aile katılım etkinlikleri önem kazanmaktadır (Çamlıbel Çakmak, 2010).

Aile ile okul işbirliği 2023 Eğitim vizyonunda temel amaçlar arasında gösterilmektedir. Aile katılımının önemi 2023 Eğitim Vizyonu Mutlu Çocuklar Güçlü Türkiye'de şu şekilde bahsedilmiştir "Unutmayalım ki dallar kökten çıkar. Ailelerin zaman, özne, nesne ve mekân ilişkilerinde gereken derinlik ve tasarruf bilincine sahip olmaları, çocuklarının doğal biçimde yeşermelerine ve yetişmelerine imkân sağlayacaktır" (MEB, 2013). Toplum Temelli Eğitim Kılavuzunda (2013) ebeveynlerin eğitimine katk1 sağlamasının öneminin üzerinde durulurken aynı zamanda aile katılımları uygulamaları vasıtasıyla ebeveynlere ulaşılabileceğini vurgulamaktadır (MEB, 2013).

Okul ve aile arasında kurulan işbirliği sonucunda çocukta, başarılı ve mutlu olarak hayata hazırlandığı gibi okul ortamını evin devamı olarak görerek güven hissi oluşmaktadır. Bununla birlikte bu işbirliği sonucunda aileler kendi değerlerinin farkına vararak çocuklarıyla sağlıklı iletişim kurabilmekte ve çocuklarıyla kaliteli zaman geçirebilmektedir. Okul ve aile işbirliği ile öğretmenler hedeflerine daha kolay ulaşabilmekte ve sağlıklı iletişim ile problemleri daha hızlı çözüme kavuşturabilmektedir (Cömert ve Güleç, 2004).

Aile katılımı ile ilgili yapılan çalışmalar incelendiğinde, aile katılımının okul öncesi eğitimde ve programındaki yeri (Yazar, Çelik ve Kök, 2008), aile katılım türleri (Chojnacka Synaszko, 2016), aile katılımı ile ilgili planlama, öğretmenin rolü, program-öğrenci-aile ve öğretmen açısından katkıları, aile katılımında yapılan yanlış uygulamalar ve aile katılımı etkinlik türleri (Çamlıbel Çakmak, 2010), okul öncesi eğitim kurumlarında aile katılımı çalışmalarının öğretmen ve veli açısından incelenmesi (Akkaya, 2007; Ünüvar, 2010; Calzada ve diğerleri, 2015; Sağlam ve Çalışkan, 2017), öğretmenler, okul yöneticileri ve ebeveynlerin aile katılımına ilişkin algıları (Erkan, Uludağ ve Dereli, 2016; Yavuz Konakman ve Yokuş, 2016), öğretmenlerin aile katılım çalışmalarına yönelik tutumları (Hannatu Aishatu, 2015; Bayraktar, Güven ve Temel, 2016), okulöncesi eğitime baba katılım düzeyi ile ilişkili değişkenlerin incelenmesi (Gürşimşek, Kefi ve Girgin, 2007), baba katılımının yeri ve önemi (Tezel Şahin ve Özbey, 2009), okul öncesi eğitimde baba katılımının öğretmen görüşlerine göre değerlendirilmesi (Özyürek vd., 2018), öğretmen ve ebeveynlerin aile katılımını etkileyen etmenlere yönelik görüşleri (Castro, Bryant, Peisner Feinberg ve Skinner, 2004; Waanders, Mendez ve Downer, 2005; La Paro, Kraft Sayre ve Pianta, 2003; Orçan Kaçan, Kimzan, Güler Yıldız ve Çağdaş, 2019) ile okul öncesi eğitimde aile katılımı engelleri ve süreçte karşılaşılan sorunlar (Günay Bilaloğlu ve Aktaş Arnas, 2019) üzerine odaklandığı görülmektedir. Yapılan araştırmalar göz önüne alındığında, okul öncesi eğitimde aile katılımını anne ve babalar açısından karşılaştırarak inceleyen çalışmaya rastlanmamıştır. Yapılan bu çalışma ile yalnız annelerin değil aynı zamanda babaların da aile katılımı düzeyleri incelenmiş, babaların aile katılımı düzeyleri anneler ile karşılaştırılarak değerlendirilmeye çalışılmıştır. 


\section{Araştırma Deseni}

\section{Yöntem}

Araştırma nicel araştırma desenlerinden tarama modeli ile yürütülmüş̧ür. Tarama modeli; bir durumu, olayı ya da grubu olduğu gibi açıklamayı, betimlemeyi amaçlayan araştırma türüdür (Ekiz, 2003). Bu doğrultuda anne ve babalarının aile katılımına ilişkin görüşlerini inceleyen bu çalışmada tarama modeli kullanılmıştır.

\section{Çalışma Grubu}

Bu araştırmanın çalışma grubunu Muğla ili merkez ilçelerinde Milli Eğitim Bakanlığı'na bağlı bağımsız anaokulları ve anasınıflarında gönüllülük esasına dayalı olarak her sınıftan iki anne ve iki baba olmak üzere toplam 148 ebeveyne ulaşılmıştır. Çalışma grubunu okul öncesi kurumuna devam eden ve normal gelişim gösteren 4-5 yaş grubu çocukların 31 anne ve 33 baba olmak üzere toplam 64 ebeveyni oluşturmuş̧tur. Çalışma grubundaki annelerin \%41.9'unun 31-35 yaş grubunda, \%22.6'sının 36-40 yaş grubunda ve \%19.4'ünün 41 yaş ve üzerinde olduğu; babaların \%36.4'ünün 31-35 yaş grubunda, \%30.3'ünün 36-40 yaş grubunda ve \%30.3'ünün 41 yaş ve üzerinde olduğu; annelerin \%38.7'sinin lisans, \%32.3'ünün lise ve \%16.1'inin ön lisans mezunu; babaların ise \%51.5'nin lisans, \%30.3'ünün lise ve \%9'inin ilkokul mezunu olduğu belirlenmiştir.

\section{Veri Toplama Araçları}

Anne ve babaların aile katılım hakkındaki görüşlerini betimlemeye yönelik Perry, Fantuzzo ve Munis $(1997,2002)$ tarafindan geliştirilen ve Ahmetoğlu, Acar, Sezer ve Akşin Yavuz (2018) tarafindan Türk kültürüne uyarlanan Aile Katılım Ölçeği (AKÖ) kullanılmıştır. Aile katılımı ölçeği orijinalinde 42 madde iken düşük faktör yük değeri ve farklı faktörlerde benzer yük değeri oluşturan 11 madde ölçekten çıkartılmış (Ahmetoğlu, Acar, Sezer ve Akşin Yavuz, 2018) ve bu araştırmada da 31 maddelik hali ile kullanılmıştır. Ölçeğin üçadet alt faktörü bulunmaktadır. Bu alt faktörler; ev-okul iş birliği temelli katılım, ev temelli katılım ve okul temelli katılım şeklindedir. Türk kültürüne uyarlaması yapılan ölçeğin alt faktörlerine göre CronbachAlpha değerleri; ev-okul iş birliği temelli katılım.88, ev temelli katılım .77 ve okul temelli katılım .84 olarak belirlenmiştir. Ölçekte ters kodlanan herhangi bir madde bulunmamakla birlikte sonuçlar ortalama puanlar üzerinden değerlendirilmektedir. Aile katılım ölçeğine ek olarak örneklem grubunu tanımlamak adına araştırmacılar tarafından oluşturulan "Genel Bilgi Formu" kullanılmıştır. Genel bilgi formunda anne babalara yönelik yaş, eğitim durumu gibi maddeler bulunmaktadır.

\section{Veri Toplama Süreci}

Araştırmanın planlandığı gibi yürütülebilmesi için gerekli izin belgeleri kurumlar arası yazışmalar sürdürülerek alınmıştır. Araştırmacılar 2018-2019 eğitim-öğretim yılı bahar döneminde okullara giderek yönetici ve öğretmenlerle görüşmüş ve araştırma hakkında bilgiler vermişlerdir. Bu doğrultuda, yedisi ilkokul bünyesinde bulunan 23 anasınıfı ile 2 bağımsız anaokulundan 14 sınıf olmak üzere toplam 10 okul ve 37 okul öncesi sınıflarında araştırmaya katılmaya gönüllü her sınıftan iki anne ve iki baba olmak üzere toplam 148 anne ve babaya, öğretmenler tarafından aile mektupları aracıllğı ile ölçekler dağıtılmıştır. Araştırmacılar iki hafta sonra okullara giderek öğretmenlerden anne ve babaların gönderdiği Genel Bilgi Formu ve Aile Katılım Ölçeklerinin doldurulmuş halini teslim almışlardır. Dağıtılan ölçeklerden 64 tanesi geri dönmüştür. Geri dönen ölçeklerden veri kaybı yaşanmamıştır. Bu kapsamda 37 okul öncesi sınıfından toplam 64 veri elde edilmiştir.

\section{Veri Analizi}

Veriler araştırmacılar tarafından bilgisayar ortamına aktarılarak analiz işlemleri SPSS paket programında gerçekleştirilmiştir. Yapılacak analizin belirlenmesi için normallik varsayımları test edilmiştir. Bu doğrultuda çarpıklık ve basıklık değerleri, histogram ve kutu grafikleri ile KolmogorovSmirnov testi incelenmiştir. Kolmogorov-Smirnov testi değerleri .05'ten büyük olsa da küçük örneklemlerde sadece bu testin sonuçları her zaman güvenilir sonuçlar vermemektedir. Çarpıklık ve basıklık değerlerinin bazıları +1 ila -1 arasında yer alamamaktadır. Ev okul işbirliği temelli aile katılımı alt ölçeğinde basıklık değeri -1,062 ve okul temelli aile katılımı alt ölçeğinde yine basıklık değeri -1,260 olarak tespit edilmiştir. Buna ek olarak incelenen histogram ve kutu grafikleri beklenilen sonuçları 
göstermediği için örneklem grubunun küçüklüğü de göz önüne alınarak daha güvenilir sonuçlar elde etmek adına Mann Whitney-U testi analiz için seçilmiştir.

\section{Bulgular}

Bu bölümde, 31 anne ve 33 babanın aile katılımı ölçeği üzerinden aldıkları puanlar incelenmektedir. Anne ve babaların ev-okul işbirliği temelli, ev temelli ve okul temelli aile katılımı faktörleri ile toplam puanları değerlendirilmektedir. Bu doğrultuda öncelikli olarak Tablo 1'de annelerin aile katılımına yönelik alt faktörlerden aldıkları puanlar ile toplam puanları gösterilmektedir.

Tablo 1

Annelerin Aile Katılımı Ölçeğinden Aldıkların Puanların Betimsel Analizleri

\begin{tabular}{lccccc}
\hline Anne & n & Min & Max & Ortalama & Ss \\
\hline Ev-Okul işbirliği temelli aile & 31 & 17 & 39 & 28,01 & 6,16 \\
katılımı & 31 & 22 & 44 & 36.43 & 5.70 \\
Ev temelli katılım & 31 & 12.56 & 39 & 25.90 & 7.80 \\
Okul temelli katılım & 31 & 55.98 & 119.34 & 90.35 & 17.23 \\
Toplam & & & &
\end{tabular}

Tablo 1'de annelerin aile katılımı ölçeğinden aldıkları puanlar faktörler üzerinden değerlendirildiğinde, ortalamanın üzerinde aile katılımı puanlarına sahip oldukları görülmektedir. Annelerin ev-okul işbirliği temelli aile katılımı alt boyutundan aldığı puan $(\bar{X}=28.01)$ ortalama değerden yüksek bir katılımı işaret etmektedir. Annelerin ev temelli aile katılımından aldığı puan ise $(\bar{X}=36.43)$ ortalama değerin üzerinde bir katılım puanını ifade etmektedir. Annelerin okul temelli aile katılımı alt faktöründen aldıkları ortalama puan $\overline{\mathrm{X}}=25.90$ 'dır. Annelerin okul temelli aile katılımından aldıkları puan yaklaşık olarak ortalama değeri ifade etmektedir. Annelerin tüm aile katılımı ölçeğinden aldıkları toplam puan $(\overline{\mathrm{X}}=90.35)$ ise ortalamanın üzerinde katılım puanı aldıklarını göstermektedir. Babaların aile katılımı ölçeğinden aldıkları toplam puan ile alt faktörlerden aldıkları puanların betimsel analizlerine Tablo 2'de yer verilmiştir.

Tablo 2

Babaların Aile Katılımı Ölçeğinden Aldıkları Puanların Betimsel Analizleri

\begin{tabular}{|c|c|c|c|c|c|}
\hline Baba & $\mathbf{n}$ & Min & $\operatorname{Max}$ & Ortalama & Ss \\
\hline $\begin{array}{lll}\begin{array}{l}\text { Ev-okul } \\
\text { katılım }\end{array} & \text { işbirliği } & \text { temelli } \\
\end{array}$ & 33 & 10 & 37.42 & 20.98 & 8.12 \\
\hline Okul temelli katılım & 33 & 10 & 30.02 & 18.79 & 5.61 \\
\hline Ev temelli katılım & 33 & 12 & 43 & 31.23 & 7.16 \\
\hline Toplam & 33 & 34 & 107.44 & 71.01 & 18.16 \\
\hline
\end{tabular}

Tablo 2'de görüldüğü üzere, babaların ev-okul işbirliği temelli aile katılımı alt faktöründen aldıkları ortalama puan $(\overline{\mathrm{X}}=20.98)$ ve okul temelli aile katılımı alt faktöründen aldıkları ortalama puanın $(\overline{\mathrm{X}}=18.79)$ ortalamanın altında olduğu gözlenmektedir. Ev temelli aile katılımından aldıkları ortalama puan ise $(\overline{\mathrm{X}}=31.23)$ annelerin aldıkları puanlara benzer şekilde ortalamanın üzerindedir. Babaların tüm ölçekten aldıkları toplam puan $(\overline{\mathrm{X}}=71.01)$ ise aile katılımında ortalamanın altında bir puana sahip olduklarını göstermektedir. Tablo 3 'te anne ve babaların ev-okul iş birliği temelli aile katılımı puanları arasında anlamlı bir fark olup olmadığı Mann-Whitney U testi ile incelenmiştir.

Tablo 3

Anne ve Babaların Ev-Okul İş Birliği Temelli Aile Katılımı Puanları İçin Mann-Whitney U Testi Sonuçları

\begin{tabular}{lccccc}
\hline Grup & n & Sira ort. & Sira top. & u & p \\
\hline Anne & 31 & 40.89 & 1267.50 & 251.500 & .000 \\
Baba & 33 & 24.62 & 812.50 & & .000 \\
\hline
\end{tabular}

Tablo 3'te anne ve babaların ev-okul işbirliği temelli aile katılımı puanları için yapılan Mann-Whitney $\mathrm{U}$ testi sonuçlarına göre aldıkları puanlar arasında anlamlı bir fark bulunmaktadır $(\mathrm{u}=251.500 ; \mathrm{p}=.000)$. $\mathrm{Bu}$ doğrultuda anne ve babaların ortalama puanları değerlendirildiğinde annelerin babalara göre ev-okul işbirliği temelli aile katılımı puanlarının daha yüksek olduğu görülmektedir. Tablo 4'te anne ve 
babaların ev temelli aile katılımı puanlarında anlamlı bir fark olup olmadığına ilişkin analiz sonuçları özetlenmektedir.

Tablo 4

Anne ve Babaların Okul Temelli Aile Katılımı Puanları Mann-Whitney U Testi Sonuçları

\begin{tabular}{lccccc}
\hline Grup & n & Sira ort. & Sira top. & u & p \\
\hline Anne & 31 & 41.10 & 1274 & 245 & .000 \\
Baba & 33 & 24.42 & 806 & & \\
\hline
\end{tabular}

Tablo 4'te görüldüğü üzere anne ve babaların okul temelli aile katılımından aldıkları puanlar arasında anlamlı bir fark görülmektedir $(\mathrm{u}=245 ; \mathrm{p}=.000)$. Anne ve babaların sıra ortalamaları göz önüne alındığında annelerin okul temelli aile katılımlarının babaların okul temelli aile katılımlarına göre oldukça yüksek olduğu görülmektedir. Tablo 5'te anne babaların ev temelli aile katılımı puanları arasında anlamlı bir fark olup olmadığı gösteren Mann-Whitney U testi analiz sonuçları bulunmaktadır.

Tablo 5

Anne ve Babaların Ev Temelli Aile Katılımı Puanları İçin Mann-Whitney U Testi Sonuçları

\begin{tabular}{lccccc}
\hline Grup & n & Sira ort. & Sira top. & u & p \\
\hline Anne & 31 & 39.61 & 1228 & 2291 & .003 \\
Baba & 33 & 25.82 & 852 & & \\
\hline
\end{tabular}

Tablo 5 anne ve babaların ev temelli aile katılım puanları arasında anlamlı bir fark olduğunu göstermektedir $(\mathrm{u}=291 ; \mathrm{p}=.003)$. Bu fark annelerin lehine olup, annelerin ev temelli aile katılımlarının babalara göre daha yüksek olduğunu belirtmektedir. Tablo 6'da anne ve babaların aile katılımı toplam puanları arasında anlamlı bir fark olup olmadığı gösteren analiz sonuçları bulunmaktadır.

Tablo 6

Anne ve Babaların Aile Katılımı Toplam Puanları İçin Mann Whitney U Testi Sonuçları

\begin{tabular}{lccccc}
\hline Grup & n & Sira ort. & Sira top. & u & p \\
\hline Anne & 31 & 41.77 & 1295 & 224 & .000 \\
Baba & 33 & 23.79 & 785 & & \\
\hline
\end{tabular}

Tablo 6'ya göre, anne ve babaların aile katılımı ölçeğinden aldıkları toplam puanlar arasında diğer alt faktörlerde olduğu gibi anlamlı bir farklılık tespit edilmiştir $(\mathrm{u}=224 ; \mathrm{p}=.000)$. Anne ve babaların ortalama puanları arasındaki belirgin fark annelerin aile katılımı puanlarının anlamlı bir şekilde daha yüksek olduğunu göstermektedir.

\section{Tartıșma, Sonuç ve Öneriler}

Araştırma bulgularına göre, annelerin ev-okul işbirliği temelli, ev temelli aile katılımı alt boyutları ve aile katılımı ölçeği toplam puanları ortalama değerin üzerinde iken okul temelli aile katılımı alt boyut puanları ortalama değere yakın bulunmuştur. Babaların ise ev-okul işbirliği temelli, okul temelli ve aile katılımı ölçeğinden aldıkları toplam puan ortalama değerin altında iken ev temelli aile katılımından aldıkları ortalama puan ise annelerin aldıkları puanlara benzer şekilde ortalamanın üzerindedir. Ayrıca anne ve babaların ölçek alt boyutları(ev-okul işbirliğii, ev ve okul temelli katılım) ve toplam ölçek puanları arasında anneler lehine anlamlı farklar olduğu görülmektedir. Bu sonuçlara göre annelerin babalara göre öğretmenle çocuğun eğitimi konusunda iletişimi içeren faaliyetlere katılımı, evde çocukları için iyi bir öğrenme ortamı oluşturma konusunda ve çocuğuyla birlikte okulda yapılan etkinliklere belirgin bir şekilde daha fazla katıldıkları söylenebilir. Bu durumun yani baba katılımının ikinci planda kalmasının, kültürel ve ekonomik sonuçlardan kaynaklandığı düşünülmektedir. Babaların ailenin geçimini sağlama rolü günümüzde hala önemini korurken, bu rolün kadınların çalışma hayatında daha fazla yer edinmeleri ile biraz daha genişlediği kabul edilmektedir.

Yapılan pek çok araştırma baba katılımının çocukların bilişsel (Zia, Malik ve Ali, 2015; Coley, Lewin Bizan and Carrano, 2011; Adedokun ve Balschweid, 2008; Grossmann, Grossmann, Fremmer Bombik, Kindler, Scheuerer Englisch ve Zimmermann, 2002; Rossi, 1984), sosyal (Öngider, 2013; Jia ve Schoppe Sullivan, 2011; Caldera, 2004; Pancsofar ve Vernon Feagans, 2006; Boyce, Essex, Alkon, 
Goldsmith, Kraemer ve Kupfer, 2006) ve duygusal (Taşkın, 2011;Notaro ve Volling, 1999) gelişimine olumlu etkileri olduğunu ortaya koymuştur.

Sağlam ve Çalışkan (2017) anne ve babaların katılımı konusunda farklılıklar olduğu, annelerin daha sorumlu tutum sergiledikleri babaların ise bu konuda daha geride kaldıkları, sorumluluk almadıkları ve bunun da aile katılımını sınırlayan önemli bir etken olduğunu öne sürmüştür. Ayrıca anne babalar aile katılımını çok ciddiye almamakla birlikte zaman sıkıntısı yaşadıklarını ve öğretmenlerin tutumlarının da aile katılımı hakkındaki fikirlerini etkilediklerini bildirmişlerdir. Bunun yanında öğretmenler, aile katılımının ne olduğuna dair doğru tanımlamalar yaparken uygulama aşamasında gösterilen önemin yetersiz olduğu düşüncesi ortaya çıkmıştır. Orçan Kaçan, Kimzan, Güler Yıldız ve Çağdaş (2019) yaptıkları çalışmada hem öğretmen hem de anne babaların aile katılımını engellenen belirgin etmenin zaman sınırlılığı olduğunu belirttiklerini ifade etmişlerdir. Güzelyurt, Birge ve Ökten (2019) okul öncesi ögretmenlerinin ailelerle iletişim kuramama ve deneyim eksikliği nedeniyle aile eğitimini önemsemediği ve aile eğitimi uygulamalarında yetersiz olduğunu bildirmişlerdir. Ayrıca Freud'un Psikanalitik Kuramı'nda ve Bowlby'nin Bağlanma Kuramı'nda ele aldıkları figürlerin “anne” olmasının yapılan diğer çalışmaları önemli oranda etkilediği ifade edilmektedir (Kocayörük, 2016). Ailenin eğitimde katılımcı olarak değil ana bileşen olarak görüldüğü ve baba katılımının çocuğun gelişimi ve eğitimi üzerindeki olumlu sonuçları göz önüne alındığında, babaların çocuğun eğitimine katılımını arttıracak kültüre ve çağın gereklerine uygun baba katılım modellerinin geliştirilerek uygulanması ve bu yolla babaların çocuk gelişimi ve eğitimi konusunda bilinçlenmesine sağlanması önerilmektedir. Bununla birlikte öğretmenlere de anne baba katılımı konusunda ihtiyaç duydukları bilgi ve becerilere yönelik kurs, seminer ve çalıştay vb. düzenlenmesi önerilmektedir.

\section{Kaynakça}

Adedokun, O. A., \& Balschweid, M. A. (2008). Community social interactive processes and rural adolescents' educational outcomes: What we know and what we need to know. The Online Journal of Rura lResearch and Policy, 2, 1-19. https://doi.org/10.4148/ojrrp.v3i2.40 adresinden alınmıştır.

Ahmetoğlu, E., Acar, İ. H., Sezer, T., \& Akşin Yavuz, E. (2018). Aile katılımı ölçeğinin Türk kültürüne uyarlanması. Abant İzzet Baysal Üniversitesi Eğitim Fakültesi Dergisi, 18(1), 1-20. DOI: 10.17240/aibuefd.2018.-368784

Akkaya, M. (2007). Öğretmenlerin ve velilerin okul öncesi eğitim kurumlarında uygulanan aile katılım çalışmalarına ilişkin görüşleri. (Yayınlanmamış yüksek lisans tezi). Anadolu Üniversitesi, Eğitim Bilimleri Enstitüsü. Eskişehir.

Bayraktar, V., Güven, G., \& Temel, Z. (2016). Okul öncesi kurumlarda görev yapan öğretmenlerin aile katılım çalışmalarına yönelik tutumlarının incelenmesi. Kastamonu Eğitim Dergisi, 24 (2) , 755 770. https://dergipark.org.tr/en/download/article-file/209722 adresinden alınmıştır.

Boyce, W.T., Essex, M. J., Alkon, A., Goldsmith, H. H., Kraemer, H. C., \& Kupfer, D. J. (2006). Early fahter involvement moderates bio-behavioral susceptibility to mental health problems in middle childhood. Journal of the American Academy of Child \&Adolescent Psychiatry, 45(12), 15101520. https://doi.org/10.1097/01.chi.0000237706.50884.8b adresinden alınmıştır.

Bronfenbrenner, U. (1981). The Ecology of Human Development. Harvard University Press: Cambridge.

Caldera, Y. M. (2004). Paternal involvement and infant-father attachment: A q-set study. Fathering, 2, 191-210.https://doi.org/10.3149/fth.0202.191 adresinden alınmıştır.

Calzada, E. J., Huang, K., Hernandez, M., Soriano, E., Acra, C. F., Dawson McClure, S., Kamboukos, D., \& Brotman, L. (2015). Urban Education, 50(7) 870-896.

Castro, D. C., Bryant D. M., Peisner Feinberg, E. S., \& Skinner M. (2004). Parent in involvement in Head Start Programs: The role of parent, teacher and classroom characteristics. Early Childhood Research Quarterly, 19(3), 413-430.

Christenson, S. (2004). The family-school partnership: An opportunity to promote the learning competence of all students. School Psychology Review, 33(1), 83-104. https://doi.org/10.1521/scpq.18.4.454.26995 adresinden alınmıştır.

Chojnacka Synaszko, B. (2016). Types of parents' involvement in early childhood development. Journal of Psychiatry and Clinical Psychology, 16(4), 204-216. 
Coley, R. L., Lewin Bizan, S., \& Carrano, J. (2011). Does early paternal parenting promotelow-income children's long-term cognitiveskills? Journal of Family Issues, 32(11), 1522-1542. https://doi.org/10.1177/0192513X11402175 adresinden alınmıştır.

Cömert, D., \& Güleç, H. (2004). Okul öncesi eğitim kurumlarında aile katılımının önemi: Öğretmenaile-çocuk kurum. Sosyal Bilimler Dergisi, 6(1). 131-145. http://hdl.handle.net/11630/3302 adresinden alınmıștır.

Çamlıbel-Çakmak, Ö. (2010). Okul öncesi eğitim kurumlarında aile katılımı. Abant İzzet Baysal $\begin{array}{llllll}\text { Üniversitesi Sosyal Bilimler Enstitüsü Dergisi, } & \text { 1(20), } & \text { 2-17. }\end{array}$ https://dergipark.org.tr/en/download/article-file/154645 adresinden alınmıştır.

Dodge, D. T., Colker, L. J., \& Heroman, C. (2002). The creative curricullum for preschool. Teaching Stategies Inc:Washington D.C.

Ekiz, D. (2003). Eğitimde araştırma yöntem ve metotlarına giriş, Ankara: Anı Yayıncılık.

Ergün, M., \& Özsüer, S. (2006). Vygotsky'nin yeniden değerlendirilmesi. Afyonkarahisar Üniversitesi Sosyal Bilimler Dergisi, 2, 269-292. http://hdl.handle.net/11630/3614 adresinden alınmıştır.

Erkan, S., Uludağ, G., \& Dereli, F. (2016). Okul öncesi öğretmenleri, okul yöneticileri ve ebeveynlerin aile katılımına ilişkin algılarının incelenmesi. Ahi Evran Üniversitesi Kırşehir Eğitim Fakültesi Dergisi, 17(1), 221-240. https://www.researchgate.net/publication/338490803 adresinden alınmıştır.

Fantuzzo, J., Tighe, E., \& Childs, S. (2000). Family involvement questionnaire: Amultivariate assessment of family participation in early childhood education. Journal of Educational Psychology, 92(2), 367-376. https://doi.org/10.1037/0022-0663.92.2.367 adresinden alınmıştır.

Green, S. (2001). Creating a father friendly child care environment. Child Care Centers Conections, $10(1), 1-4$.

Grossmann, K., Grossmann, K. E., Fremmer Bombik, E., Kindler, H., Scheuerer Englisch, H., \& Zimmermann, A.P. (2002). The uniqueness of the child-father attachment relationship: Fathers sensitive and challenging play as a pivotal variable in a 16-year long itudinal study. Social Development, 11(3), 301-337. https://doi.org/10.1111/1467-9507.00202 adresinden alınmıştır.

Günay-Bilaloğlu, R., \& Aktaş Arnas, Y. (2019). Okul öncesi eğitimde aile katılımı engelleri ve süreçte karş1laş1lan sorunlar. Hacettepe Üniversitesi Eğitim Fakültesi Dergisi, 34(3), 804-823. Retrieved from https://dergipark.org.tr/tr/pub/hunefd/issue/47441/598517

Gürşimşek, I., Kefi, S., \& Girgin, G. (2007). Okulöncesi eğitime babaların katılım düzeyi ile ilişkili değişkenlerin incelenmesi. Hacettepe Üniversitesi Eğitim Fakültesi Dergisi, (33), 181-191. Retrieved from https://dergipark.org.tr/tr/pub/hunefd/issue/7805/102351

Güzelyurt, T., Birge, F., \& Ökten, A. (2019). Okul öncesi öğretmenlerinin aile katılımına ilişkin görüşleri. Kocaeli Üniversitesi Eğitim Dergisi, 2(1), 64-74. DOI: 10.33400/kuje.538425

Hannatu Aishatu, A. (2015). An exploratory study of early childhood development teacher attitudes towards parent involvement in early childhood development centres in Athlone. (Unplished MSthesis), University of Cape Town, Retrieved from http://hdl.handle.net/11427/13271

Jia, R., \& Schoppe Sullivan, S.J. (2011). Relations between coparenting and father involvement in families with preschool aged children. Developmental Psychology, 47, 106-118. doi: $10.1037 / a 0020802$

Keçeli-Kaysılı, B. (2008). Akademik başarının arttırılmasında aile katılımı. Ankara Üniversitesi Eğitim Bilimleri Fakültesi Özel Ĕ̈itim Dergisi, 9(1), 69-83. DOI: 10.1501/Ozlegt_0000000115

Kocayörük, E. (2016). Ergen gelişiminde aile işlevleri ve baba katılımı. Türk Psikolojik Danışma ve Rehberlik Dergisi, 4(33), 37-45.

Koch, L. A. (2018). Parent involvement in early childhood education and its impact on the development of early language and literacy skills: An exploration of one Head Start Program's parent involvement model. (Unplished Doctor of Thesis). Drexel University, U.S.A.

La Paro, K. M., Kraft Sayre, M., \& Pianta, R.C. (2003). Preschool to kindergarten transition activities: Involvement and satisfaction of families and teachers. Journal of Research in Childhood Education, 17 (2), 147- 158.

Kurtulmuş, Z. (2016). Okul öncesi eğitimde uygulanan etkinlik planlarında aile katılımı boyutunun incelenmesi. Cumhuriyet International Journal of Education, 5(1), 78-84. DOI: 10.30703/cije.321384 
Milli Eğitim Bakanlığı, Mutlu Çocuklar Güçlü Türkiye 2023 Eğitim Vizyonu. http://2023vizyonu.meb.gov.tr/ adresinden alınmıștır.

Milli Eğitim Bakanlığı. (2013). Yerel Yönetimler, Sivil Toplum Kuruluşları, Kamu Kuruluşları ve İşveren Kuruluşları için Toplum Temelli Erken Çocukluk Hizmetleri Sunumu Kılavuzu. Ankara.

Notaro, P. C., \& Volling, B.L. (1999). Parental responsiven essand infant-parent attachment: A replication study with fathers and mothers. Infant Behavior and Development, 22, 345-352. Retrieved from https://doi.org/10.1016/S0163-6383(99)00012-0

Orçan Kaçan, M., Kimzan, İ, Güler Yıldız, T., \& Çağdaş, A. (2019). Öğretmen ve ebeveynlerin aile katılımını etkileyen etmenlere yönelik görüşlerinin incelenmesi. Eğitim Kuram ve Araştırmaları Dergisi, 5(3), 370-381. Retrieved fromhttps://dergipark.org.tr/tr/download/article-file/907151

Öncül, F. (2011). Öğretmenlerin yapmış olduğu ev ziyaretlerinin aile üzerindeki etkisi. (Yayınlanmamış yüksek lisans tezi). Gazi Üniversitesi Eğitim Bilimleri Enstitüsü. Ankara.

Öngider, N. (2013). Anne-baba ile okul öncesi çocuk arasındaki ilişki psikiyatride güncel yaklaşımlar. Current Approaches in Psychiatry, 5(4),420-440. DOI: 10.5455/cap.20130527

Özel, E., Çağdaş, A., \& Konca, A.S. (2016). İlkokul başlangıcında velilerin aile katılım düzeylerinin incelenmesi. Eğitimde Kuram ve Uygulama, 12(4), 891-908. Retrieved from https://dergipark.org.tr/tr/pub/eku/issue/24403/258692

Özyürek, A.,Şalcı, O., Mamiyev, D., Çekiç, İ., Sağlam, C., \& Nazlı, B. (2018). Okul öncesi eğitimde baba katılımının öğretmen görüşlerine göre değerlendirilmesi. Uludağ Üniversitesi Ĕ̌gitim Fakültesi Dergisi, 31(2) , 613-631. DOI: 10.19171/uefad.505618

Pancsofar, N., \& Vernon Feagans, L. (2006). Mother and father language inputto young children: Contributions to later language development. Journal of Applied Developmental Psychology, 27, 571- 587. DOI: 10.1016/j.appdev.2006.08.003

Perry, M.A., Fantuzzo, J., \& Munis, P. (2002). Family involvement questionnaire(FIQ). Philadelphia, PA: University of Pennsylvania.

Rossi, A. (1984). Genderandparenthood. American Sociological Review, 49, 1-10. Stable URL: https://www.jstor.org/stable/2095554

Sağlam, M., \& Çalışkan, Z. (2017). Okul öncesi eğitimde aile katılımına ilişkin ebeveyn ve öğretmen görüşlerinin değerlendirilmesi. Uluslararası Erken Çocukluk Eğitimi Çalışmaları Dergisi, 2(2), 39-49. Retrieved from http://ijeces.hku.edu.tr/tr/issue/31378/332297

Taşkın, N. (2011). Çocukların Gelişiminde Katkıları Unutulanlar: Babalar. Eğitim Bir Sen Dergisi, 20, 43-47.

http://www.vizyon21y.com/documan/Egitim Ogretim/Egitim/Egitim Makaleleri/Cocuklarin G elisiminde Katkilari Unutulanlar Babalar.pdf adresinden alınmıştır.

Tezel Şahin, F., \& Özbey, S. (2009). Okul öncesi eğitim programlarında uygulanan aile katılım çalışmalarında baba katılımının yeri ve önemi. Aile ve Toplum, 5(17), 30-39. Retrieved from https://dergipark.org.tr/en/download/article-file/198193

Tezel-Şahin, F., \& Özyürek, A. (2016). Anne Baba Ĕ̈itimi ve Aile Katılımı. Ankara: İstatistik Dünyas1.

Ünüvar, P. (2010). Aile katılımı çalışmalarına yönelik ebeveyn ve öğretmen görüşlerinin karş1laştırılması. Kastamonu Ĕ̈itim Dergisi, 18(3), 719-730. Retrieved from https://dergipark.org.tr/en/download/article-file/817592

Waanders, C., Mendez J. L., \& Downer J. T. (2005). Parent characteristics, economic stres and neighborhood context as predictors of parent involvement in preschool children's education. Journal of School Psychology, 45(6), 619-636.

Yaşar-Ekici, F. (2017). Okul öncesi eğitim kurumlarındaki aile katılım çalışmalarına katılan ve katılmayan ailelerin çocuklarının sosyal beceri ve problem davranışları arasındaki ilişki. Hitit Üniversitesi Sosyal Bilimler Enstitüsü Dergisi, 10(1), 543-562. Retrieved from https://dergipark.org.tr/tr/pub/mkusbed/issue/24546/259991

Yavuz-Konakman, G., \& Yokuş, G. (2016). Ebeveynlerin okul öncesi eğitime katılım düzeylerine ilişkin algıları. Mustafa Kemal Üniversitesi Sosyal Bilimler Enstitüsü Dergisi, 13(35), 176-193. Retrieved from https://dergipark.org.tr/tr/pub/mkusbed/issue/24546/259991 
Yazar, A., Çelik, M., \& Kök, M. (2008). Aile Katılımının okul öncesi eğitimde ve 2006 okul öncesi eğitim programındaki yeri. Atatürk Üniversitesi Sosyal Bilimler Enstitüsü Dergisi, 12, 233-243. Retrieved from https://dergipark.org.tr/tr/pub/ataunisosbil/issue/2822/38076

Zia, A., Malik, A. A., \& Ali, S. M. (2015). Father and daughter relationship and its impact on daughter's self-esteem and academic achievement. Academic Journal of Interdisciplinary Studies, 4(1), 311316. DOI: $10.5901 / \mathrm{mjss} .2015 . v 4 n 1 \mathrm{p} 311$ 